\title{
Nepalese EFL Teachers' Digital Literacy for Online Teaching
}

\author{
Mohan Singh Saud \\ Far Western University, Dhangadhi, Nepal \\ mssaud35@gmail.com
}

\begin{abstract}
ARTICLE HISTORY
Received : 2021-02-10

Revised : 2021-04-14

Accepted : 2021-04-18
\end{abstract}

\section{KEYWORDS}

Digital literacy

EFL teachers

Online teaching

Global pandemic

Face-to-face teaching

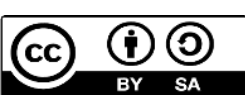

\begin{abstract}
The face-to-face mode of delivery had significantly been affected by the COVID19 pandemic. Due to its spread, the government had suspended the traditional classroom teaching system, requiring its alternative online teaching instead. Accordingly, English teachers needed to be prepared with the necessary digital literacy skills for effective online teaching. Considering this situation, this study sought to survey the digital literacy skills of secondary school level English teachers of Nepal to check their preparedness for online delivery. A questionnaire was prepared through Google Docs and circulated to English teachers through emails and Messenger. Data was collected using the snowball-sampling method. Altogether, 426 English teachers across the country participated in this study. This study found that secondary school-level English teachers possess the necessary digital literacy skills like word processing, the use of the Internet, downloading, online presentations, and hence, are prepared for an online teaching mode.
\end{abstract}

\section{Introduction}

The outbreak of the COVID-19 global pandemic has greatly affected almost all aspects of life across the world (e.g. physical distancing, mental stress, travel restrictions, unemployment, local services and suspension of face-to-face classes) (MacIntyre et al., 2020; Aliyyah et al., 2020). Among such changes, this crisis has brought an enormous challenge to education systems worldwide at all levels of teaching, forcing many governments to order educational institutions to suspend in-person classes and recommend a shift to online distance teaching (Daniel, 2020) instead. The fear of spreading coronavirus to the children was the main reason to close the schools worldwide to break the chain of transmission (Uscher-Pines et al., 2018; Abdulamir \& Hafidh, 2020). The global spread of the COVID-19 has caused the suspensions of face-to-face classes requiring online teaching and learning (Moorhouse, 2020). In this context, Dhawan (2020) argues that online learning can be a panacea in the COVID-19 crisis. To continue the education system during this crisis, online teaching is the only option and necessity. The COVID-19 pandemic has forced EFL teachers to go for online teaching as an alternative to previous face-to-face classroom teaching. Many EFL teachers had not been prepared for the online mode of instruction before COVID-19, as they did not feel any need at that time, but now the situation requires this approach (MacIntyre et al., 2020).
Acquiring digital literacy is an essential prerequisite in online teaching contexts. There has been a growing interest in the use of information and communication technology (ICT) in English as a foreign language (EFL) due to the widespread application of computers and technology in education (Dashtestani \& Hojatpanah, 2020). Proper knowledge about computers is, of course, a prerequisite for EFL teachers and students in technology-enhanced language teaching and learning. Son et al. (2011) define computer literacy as "the development of knowledge and skills for using general computer applications, language-specific software programmes, and Internet tools confidently and competently" (p. 27) concerning language teacher education. In the twenty-first century, computer skills are as necessary as language skills to both teachers and learners for effective online teaching and learning. Computer literacy underlies digital literacy, which is defined as "the ability to use information and communication technologies to find, evaluate, create, and communicate information, requiring both cognitive and technical skills" (Digital Literacy Task Force, 2013, p. 2). Online teaching can be purposeful and effective when EFL teachers command digital literacy in a teaching environment. The necessity of developing digital literacy has come abruptly due to the sudden outbreak of the COVID-19 worldwide. 


\section{Literature Review}

Nepal's educational system has traditionally been face-to-face teaching and learning. Only the highly infrastructured private schools in urban areas have adopted Computer Assisted Language Learning (CALL) to some extent only, as my observation and experience shows. The government-aided public schools rarely adopt CALL due to the lack of computer-based facilities and computer literacy among teachers. However, the COVID-19 pandemic has dramatically affected the face-to-face classroom teaching and learning environment worldwide, including Nepal. COVID-19 resulted in lockdown, staying in isolation, social distancing, the necessity of wearing masks, and so on. Due to the lockdown and the spread of the COVID-19, the Nepal government has stopped traditional classroom teaching and encouraged its alternative, online teaching. In this context, most of the schools in urban areas have started online teaching for students with Internet access with the computer or mobile telephones. However, online teaching and learning have still been a dream for students from remote rural areas, yet unattained.

As school courses have been designed for a face-toface mode of instruction, EFL teachers need to adapt them to make them suitable for online teaching. In this scenario, this study examined the Nepalese EFL teachers' digital literacy, which could be helpful to shift to online instruction. Due to the suspension of traditional face-to-face classroom instruction in schools, the courses had to be delivered through online mode exclusively. Considering this issue, this study aimed at examining the EFL teachers' digital literacy and sought to determine if they were ready for online teaching in the context of Nepal, especially during COVID-19. Therefore, this study can be pretty significant for the EFL teachers to be prepared for online teaching as an alternative to traditional face-toface classroom teaching. Nonetheless, technological knowledge is needed for EFL teachers as the twentyfirst-century teacher knowledge along with pedagogical and content knowledge (see the technological pedagogical content knowledge (TPACK) model of Mishra and Koehler (2006). However, this study surveyed EFL teachers from school levels only having their computer application skills with the Internet access and facilities, as data was collected through the online system.

There have been some research studies into the digital literacy skills of English language teachers around the world. To review some, Son et al. (2011) reviewed the skills of Indonesian English language teachers and found that their frequency of using computer applications in the classroom was minimal despite having positive attitudes towards CALL.
Mudra (2020) studied the benefits from and barriers to digital literacy from the EFL teachers' and learners' perspectives and found that there were both benefits and barriers of digital literacy for young learners in learning English. This study was conducted in the Indonesian educational context. Similarly, Dashtestani and Hojatpanah (2020) studied the digital literacy of EFL students in a junior high school in Iran and found that they had a low to moderate level of digital literacy. Moreover, some studies have been conducted on teachers' perceptions of literacy and use of technology in classroom practice (Lawrence \& Calhoun, 2013), teachers' perceptions about the use of computers in EFL teaching and learning (Aydin, 2013), EFL teachers' use of the Internet in teaching language (Chen, 2008), including perceptions of the level of digital literacy (Çam \& Kiyici, 2017). These studies guided me in my research concerning finding out the digital literacy skills of the EFL teachers in the context of Nepal and determining whether they were prepared for online teaching during COVID-19 and other such crises.

However, the COVID-19 pandemic crisis has demonstrated the need for the readiness of EFL teachers to practise online teaching for the continuation of the education system. The case study conducted by Basilaia and Kvavadze (2020) in a private school in Georgia about implementing online education confirmed that the quick transition to the online form of education was successful. Atmojo and Nugroho's (2020) study in Indonesia showed that online learning did not run well due to the lack of preparation and planning. Most of the studies have been on other issues rather than digital literacy, such as language teachers' coping strategies during the COVID-19 shifting to online teaching (MacIntyre et al., 2020), perceptions of school teachers of online learning during the COVID19 pandemic (Aliyyah et al., 2020), teaching activities and challenges during COVID-19 pandemic (Atmojo \& Nugroho, 2020), and university student's readiness for online learning (Chung et al., 2020). As these studies show, little research has been done on the digital literacy skills of the EFL teachers in the world. Although a few studies have focused on using ICT with teaching language in Nepal (Acharya, 2014; Thapaliya, 2014; Rana et al., 2018), there has been no research on school-level EFL teachers' digital literacy in Nepal. In this context, the current study sheds new light compared to existing studies, especially in Nepal.

\section{Method \\ 3.1 Research Design}

This study was set out to examine the school level EFL teachers' digital literacy in Nepal and determine whether they were ready for online teaching. To achieve this objective, this study employed a 
quantitative survey research design. The survey tool was adapted from questionnaires created by Son et al. (2011) and Cote and Milliner (2018), making it suitable to examine the Nepalese school level EFL teachers' digital literacy, which would help them to be ready for online teaching during the COVID-19 pandemic and other such crises (see Appendix). Then it was shown to the experts to judge its reliability.

\subsection{Participants}

A total of 426 Nepalese EFL teachers participated in the study. The snowball sampling technique was used with an online survey tool to collect data as it was hard to find the potential participants during the COVID-19 crisis and the lockdown period though this way of collecting data cannot be considered random and representative of the target population.

The total number of participants was $426 \mathrm{EFL}$ teachers teaching in different schools in Nepal from primary to secondary levels. In terms of gender, 336 participants were males while 90 were females. In terms of age groups, 239 were below 35 years of age while 13 participants were above 50. Regarding provinces, the majority of the participants were from Bagmati Province $(\mathrm{N}=117)$. Regarding their academic qualifications, most of the participants $(\mathrm{N}=322)$ held master's degree and 20 M.Phil./PhDs. None of the participants were undergraduates. Similarly, in terms of years of experience, 82 participants had less than five years of experience, and 36 participants had more than twenty years of experience. With the working area, 227 participants were from rural areas and 119 from urban areas. The majority of the participants $(\mathrm{N}=222)$ were permanent employees working in the government sector $(\mathrm{N}=319)$. This demographic information can be shown in table 1 below.

Table 3.1 Participant Profile $(\mathrm{N}=426)$

\begin{tabular}{|c|c|c|c|}
\hline Variable & Category & Number & Percentage $\%$ \\
\hline \multirow{2}{*}{ Gender } & Male & 336 & $79 \%$ \\
\hline & Female & 90 & $21 \%$ \\
\hline \multirow{5}{*}{ Age } & below 35 years & 239 & $56 \%$ \\
\hline & $35-40$ years & 111 & $26 \%$ \\
\hline & 41-45 years & 41 & $10 \%$ \\
\hline & $46-50$ years & 22 & $5 \%$ \\
\hline & above 50 years & 13 & $3 \%$ \\
\hline \multirow{7}{*}{ Province } & Province 1 & 40 & $9 \%$ \\
\hline & Province 2 & 26 & $6 \%$ \\
\hline & Bagmati & 117 & $27 \%$ \\
\hline & Gandaki & 28 & $7 \%$ \\
\hline & Province 5 & 58 & $14 \%$ \\
\hline & Karnali & 45 & $11 \%$ \\
\hline & Far Western & 112 & $26 \%$ \\
\hline \multirow{4}{*}{ Academic qualification } & Plus two/Intermediate/PCL & 0 & $0 \%$ \\
\hline & Bachelor's & 83 & $19 \%$ \\
\hline & Master's & 322 & $76 \%$ \\
\hline & M.Phil./PhD & 20 & $5 \%$ \\
\hline \multirow{5}{*}{ Teaching experience } & Less than five years & 82 & $19 \%$ \\
\hline & $5-10$ years & 155 & $36 \%$ \\
\hline & $11-15$ years & 113 & $27 \%$ \\
\hline & $16-20$ years & 40 & $9 \%$ \\
\hline & More than 20 years & 36 & $9 \%$ \\
\hline \multirow{2}{*}{ Working area } & Urban & 199 & $47 \%$ \\
\hline & Rural & 227 & $53 \%$ \\
\hline \multirow{3}{*}{ Employment status } & Permanent & 222 & $52 \%$ \\
\hline & Temporary & 185 & $43 \%$ \\
\hline & Part-time & 19 & $5 \%$ \\
\hline \multirow{2}{*}{ Employment sector } & Government & 319 & $75 \%$ \\
\hline & Private & 107 & $25 \%$ \\
\hline
\end{tabular}




\subsection{Data Collection and Analysis Procedures}

The survey questionnaire was administered via Google Docs between September 2 to 23, 2020. The survey was shared through personal email contacts and via social media networks, asking the respondents to forward it to other school level EFL teachers they knew. After three weeks in the field, the web survey received 426 responses from all the seven provinces of Nepal. Data collected in this way was analysed in terms of the simple statistical method of percentages.

\section{Findings}

This study aimed at examining the digital literacy of the Nepalese school level EFL teachers. The following sections present the study results collected through an online survey system using Google Docs in terms of themes with statistical percentage.

\subsection{Ownership of Digital Devices}

All respondents have digital devices. As evidenced in Table 4.1, the majority of the teachers own a smartphone $(70 \%)$. A high percentage possesses a laptop (68\%). Only 16 teachers own other devices.

Table 4.1 Digital Device Ownership ( $=424)$

\begin{tabular}{lccc}
\hline & Device & Number & Percentage $\%$ \\
\hline Desktop computer & 79 & $19 \%$ \\
Laptop & 289 & $68 \%$ \\
Tablet & 39 & $9 \%$ & $70 \%$ \\
Smartphone & 295 & $4 \%$ \\
Others & 16 & $4 \%$ \\
\hline
\end{tabular}

The ownership of the digital devices is the first requirement for EFL teachers to conduct online teaching. Considering this issue, this study checked whether they have such devices or, if yes, which type of devices they possess. The result showed that almost all the participants had one or another digital device for online teaching. It shows their preparedness for online delivery.

\subsection{Computer Skills of the EFL Teachers}

EFL teachers were asked whether they could perform the tasks related to digital skills. Overall, they were very confident at completing the computerrelated tasks. However, the tasks that involved installing a software programme, resizing photographs, and recording and editing sounds had the highest number $\mathrm{f}$ 'No' responses, although they were below $50 \%$ (Table 4.2).

Table 4.2 Computer Skill Related Questions

\begin{tabular}{|c|c|c|}
\hline Questions & Yes $\%$ & No\% \\
\hline 1. Can you properly turn on and shut down a computer? & $99 \%$ & $1 \%$ \\
\hline 2. Can you start and exit a computer programme? & $98 \%$ & $2 \%$ \\
\hline 3. Can you scan a disk or file for viruses? & $84 \%$ & $16 \%$ \\
\hline 4. Can you create a basic Microsoft Word document? & $92 \%$ & $8 \%$ \\
\hline 5. Can you send and receive attachments through email messages? & $97 \%$ & $3 \%$ \\
\hline 6. Can you move a file from a hard drive to a USB drive? & $92 \%$ & $8 \%$ \\
\hline 7. Can you download and save files from the web? & $97 \%$ & $3 \%$ \\
\hline 8. Can you change the font style and size in a document? & $94 \%$ & $6 \%$ \\
\hline 9. Can you copy, cut and paste inside a document? & $96 \%$ & $4 \%$ \\
\hline 10. Can you make slides for the presentation using PowerPoint? & $88 \%$ & $12 \%$ \\
\hline 11. Can you search for information using a web search engine? & $94 \%$ & $6 \%$ \\
\hline 12. Can you change monitor brightness and contrast? & $89 \%$ & $11 \%$ \\
\hline 13. Can you minimise, maximise and move windows on the desktop? & $90 \%$ & $10 \%$ \\
\hline 14. Can you perform file management, including deleting and renaming files, etc.? & $91 \%$ & $9 \%$ \\
\hline
\end{tabular}


Regarding the level of digital skills on a scale of one to four, EFL teachers were asked to rate their digital skills and application (Table 4.3). The majority of the participants rated their computer literacy, digital literacy and typing skills as adequate and reasonable. It is essential that EFL teachers need digital literacy to smooth use of online devices that can be used while teaching online. The higher the level of digital literacy, the better for effective online delivery of the class. Therefore, it was considered better to check to what extent the EFL teachers possess digital literacy, and the result showed adequate digital literacy skills for effective online teaching.

Table 4.3 EFL Teachers' Self-assessment of Digital Skills

\begin{tabular}{ccccc}
\hline $\begin{array}{c}\text { What is your level of digital skills and their } \\
\text { application? }\end{array}$ & $\begin{array}{c}\text { Excellent } \\
\text { Computer literacy }\end{array}$ & Good & Adequate & Poor \\
Digital literacy & $12 \%$ & $57 \%$ & $30 \%$ & $1 \%$ \\
Current typing skills & $8 \%$ & $54 \%$ & $36 \%$ & $2 \%$ \\
\hline
\end{tabular}

When asked to rate their level of knowledge about the use of computer/digital skills, many EFL teachers self-assessed to have basic or intermediate skills (Table 4.4). Only a few had lower application skills, while some were advanced. It means that the EFL teachers in Nepal have digital skills like word processing, Internet and email, presentation applications, web search engines, downloading and installing programmes, online presentation and discussion, online chat and multimedia applications. The majority of them had intermediate knowledge about the use of digital skills, which seems to be enough for their effective online teaching.

Table 4.4 Level of Knowledge about the Use of Digital Skills

\begin{tabular}{lcccc}
\hline $\begin{array}{l}\text { How would you rate your knowledge about the use of } \\
\text { computer/digital skills? }\end{array}$ & None (1) & Basic (2) & Intermediate (3) & Advanced (4) \\
\hline Word processing & $3 \%$ & $51 \%$ & $33 \%$ & $13 \%$ \\
Internet & $1 \%$ & $42 \%$ & $40 \%$ & $17 \%$ \\
Email & $2 \%$ & $38 \%$ & $38 \%$ & $22 \%$ \\
Presentation applications & $8 \%$ & $42 \%$ & $37 \%$ & $13 \%$ \\
Web search engines & $7 \%$ & $43 \%$ & $34 \%$ & $16 \%$ \\
Downloading and installing programmes & $5 \%$ & $40 \%$ & $36 \%$ & $19 \%$ \\
Online presentation and discussion & $8 \%$ & $42 \%$ & $36 \%$ & $14 \%$ \\
Online chat & $1 \%$ & $32 \%$ & $39 \%$ & $28 \%$ \\
Multimedia applications & $6 \%$ & $46 \%$ & $34 \%$ & $14 \%$ \\
\hline
\end{tabular}

Table 4.5 summarises EFL teachers' responses to the question Who taught you how to use a computer in the first place? Although they learned from a range of sources, most of them learned from formal training $(41 \%)$. Informal self-learning seems to be typical as
$34 \%$ of respondents reported learning by themselves. EFL teachers learned computer skills from one or another source. As the table shows, the majority learned computer by training. Since EFL teachers' preparedness requires computer skills, it was 
considered that it was necessary to check from which sources they gained computer knowledge.

Table 4.5 Learning Source $(\mathrm{N}=426)$

\begin{tabular}{lcc}
\hline \multicolumn{1}{c}{ Who taught you how to use a computer in the first place? } & Number & Percentage \% \\
\hline Trainer/Teacher & 176 & $41 \%$ \\
Family & 20 & $5 \%$ \\
Books & 2 & $1 \%$ \\
Colleagues & 24 & $6 \%$ \\
Friends & 36 & $8 \%$ \\
YouTube videos & 21 & $5 \%$ \\
Self/Yourself & 147 & $34 \%$ \\
\hline
\end{tabular}

\subsection{EFL Teachers' Readiness for Online Teaching}

EFL teachers need access to the Internet along with a digital device. Table 4.6 reflects that most respondents have computers/laptops to facilitate online teaching with their email accounts and Internet access. For online teaching, EFL teachers needed computer access and usage. Therefore, the questions presented in
Table 4.6 were asked to check whether they had computers and/or laptops and emails and Internet access without which online teaching could never be imagined. The majority of them responded that they had all this access. It means that they were prepared for online delivery of lesson during the COVID-19 pandemic.

Table 4.6 Computer Access and Usage Related Questions

\begin{tabular}{llc}
\hline \multicolumn{1}{c}{ Question } & Yes $\%$ & No $\%$ \\
\hline 10. Do you have a personal computer or a laptop to facilitate online teaching? & $80 \%$ & $20 \%$ \\
15. Do you have an email account? & $99 \%$ & $1 \%$ \\
17. Do you have a computer/laptop with access to the Internet at home? & $75 \%$ & $25 \%$ \\
\end{tabular}

The COVID-19 pandemic has compelled schools to prepare for online teaching as far as possible. The majority of the respondents (54\%) responded that their schools had not provided online teaching (Table 4.7). Although $78 \%$ of the participants responded that they were not involved in online teaching before this pandemic, they have been involved in it during this period. Most of the EFL teachers in Nepal think that online teaching is not a burden for them.

Table 4.7 Online Teaching Related Questions

\begin{tabular}{lcc}
\hline \multicolumn{1}{c}{ Question } & Yes \% & No \% \\
\hline 16. Has your school made provision for online teaching? & $46 \%$ & $54 \%$ \\
18. Are you involved in online teaching during this pandemic period? & $62 \%$ & $38 \%$ \\
23. Were you involved in online teaching before COVID-19? & $78 \%$ & $22 \%$ \\
26. Do you think online teaching is a burden for EFL teachers? & $17 \%$ & $83 \%$
\end{tabular}

When asked whether EFL teachers were ready for online teaching during the COVID-19 pandemic and other such crises, most of the respondents $(88 \%)$ replied 'Yes' (Table 4.8). It means that without digital preparedness, online teaching could never be possible. The main concern of this study was the same. From the 
result, it became clear that most participants were prepared for online teaching during the pandemic. When the government-run online mode of teaching,

Table 4.8 EFL Teachers' Readiness for Online Teaching

\begin{tabular}{lccc}
\hline \multicolumn{1}{c}{ Question } & Yes \% & Maybe \% & No \% \\
\hline $\begin{array}{l}\text { 19. Are you prepared for online teaching during the COVID-19 pandemic and } \\
\text { other such crises? }\end{array}$ & $88 \%$ & $11 \%$ & $1 \%$ \\
\hline
\end{tabular}

\subsection{EFL Teachers' Involvement in Online Teaching}

Regarding using a digital device for online teaching, EFL teachers have one or more devices, as they became involved in it as they made themselves ready for it.
Table 4.9 shows. The majority of them $(68 \%)$ use a laptop.

Table 4.9 Digital Device Used for Online Teaching

\begin{tabular}{lcc}
\hline \multicolumn{1}{c}{ Which device do you use for online teaching? } & Number & Percentage \% \\
\hline Desktop computer & 41 & $10 \%$ \\
Laptop & 286 & $68 \%$ \\
Smartphone & 259 & $61 \%$ \\
None & 16 & $4 \%$ \\
\hline
\end{tabular}

In response to the question What type of communication tool do you use in online teaching activities?, the majority of EFL teachers responded that they use Zoom (91\%) although they also use other tools (Table 4.10). It means that different communication tools were used in online teaching by the EFL teachers while online classes were run. The most common

Table 4.10 Communication Tool Used in Online Teaching

\begin{tabular}{lcc}
\hline \multicolumn{1}{c}{ What type of communication tool do you use in online teaching activities? } & Number & Percentage \% \\
\hline Zoom & 382 & $91 \%$ \\
Microsoft Teams & 92 & $22 \%$ \\
Google Meet & 150 & $36 \%$ \\
Messenger & 190 & $45 \%$ \\
Other & 16 & $3 \%$ \\
\hline
\end{tabular}

\subsection{Online Teaching in Nepal}

Regarding the necessity of online teaching in Nepal, most of the respondents replied that it is the digital age demand $(65 \%)$, while some of them had mixed responses (Table 4.11). With the future of online teaching in Nepal, most of them $(76 \%)$ responded that it was just an alternative to continue the education system during a pandemic or similar crises, although among them were Zoom, Microsoft Teams, Google Meet and Messenger. The majority of them used Zoom as it was easier to operate. Without the use of any one of these tools, online teaching could not have been conducted. some responded with both options (Table 4.11). As Nepal is one of the least developed countries, online teaching is not so more accessible. There is a lack of Internet access in all parts of the country. Therefore, online teaching is not so easier as it is imagined. Only a few people, mainly in the urban areas, have Internet access. Nonetheless, it is the demand of the digital age and technological development. 
Table 4.11 Necessity of Online Teaching in Nepal

\begin{tabular}{lcc}
\hline What do you think about online teaching in Nepal? & Number & Percentage \% \\
\hline Necessity & 149 & $35 \%$ \\
Compulsion & $275 \%$ \\
The demand of the digital age & $65 \%$ \\
\hline
\end{tabular}

Regarding the future of the online teaching system in Nepal, it cannot replace the traditional face-to-face classroom teaching as there are no such infrastructures for the effective use of online mode. Therefore, it can just be an alternative to continue the education $n$ system during a pandemic or other similar crises. It can still take a long period to use the online mode of teaching.

Table 4.11 Future of Online Teaching System in Nepal

\begin{tabular}{|c|c|c|}
\hline What do you think about the use of an online teaching system in Nepal? & Number & Percentage $\%$ \\
\hline Replacement of the traditional face-to-face classroom teaching & 127 & $30 \%$ \\
\hline Just an alternative to continuing the education system during a pandemic or similar crises & 323 & $76 \%$ \\
\hline
\end{tabular}

The majority of the respondents doubt (49\%) whether online teaching can be relevant and effective in the context of Nepal (Table 4.12). What can be inferred from this is that online teaching may not be relevant and effective in Nepal due to the lack of infrastructures and the easy access on the Internet to all the places. Then face-to-face mode of delivery is the only way in the formal education system in schools of Nepal.

Table 4.12 Effectiveness of Online Teaching in Nepal

\begin{tabular}{ccc}
\hline Question & Yes $\%$ & Maybe $\%$ \\
\hline 28. Can online teaching be relevant and effective in the context of Nepal? & $33 \%$ & $49 \%$ \\
\hline
\end{tabular}

\section{Discussion}

The study results indicate that school level EFL teachers in Nepal have adequate digital literacy for online teaching during the COVID-19 pandemic and other such crises. They have prepared themselves and are ready for the online mode of instruction. Interestingly, $53 \%$ of respondents were from rural areas of Nepal. Most of them possess a laptop and/or smartphone as the digital devices used for online delivery. They have good computer skills in the primary application of tools. Although most of them took training to learn computer skills, some selflearned during lockdown and pandemic periods.

EFL teachers in Nepal are ready for online teaching with digital devices and Internet access even though they were not involved in online teaching before the COVID-19 pandemic. This pandemic has made them ready for online instruction. However, most of them reported that their schools had not made any provision for online teaching, presumably because of the weakness of the school management system and administration. Nonetheless, some schools have started online instruction in the areas where there is access to electricity, the Internet and digital devices for learning.

Those EFL teachers involved in the online delivery of content mainly used Zoom as a communication tool for teaching-learning activities, while some used Messenger. Teachers have mixed opinions regarding the necessity of online teaching in Nepal, most of them responding that it is a requirement of the digital age in the 21st century. Since Nepal had adopted the traditional face-to-face mode of teaching, the online mode can be an alternative to continue the education system during a pandemic or similar crisis, as responded by most participants.

The majority of them doubted that the online mode could be relevant and effective in the context of Nepal. Their doubt is as expected because Nepal is a country with remote mountain, hill and plain areas, where there 
is still no access to electricity, telephone networks and the Internet in most of these regions. All teachers and students do not have access to the Internet in all areas. Because of this reason, online teaching cannot be effective in the context of Nepal. Therefore, their doubt can be justifiable.

This study is different from the previous studies as cited above (e.g. Mudra, 2020; Dashtestani \& Hojatpanah, 2020) in that all the other studies reflect simply EFL teachers and students digital literacy skills necessary for online teaching and learning in any season, but this study explored the digital literacy skills of the EFL teachers in the context of Nepal. Classes were never online in Nepal, but due to the COVID-19 pandemic, all the schools were closed due to lockdown by the government. It resulted in hampering teachinglearning activities. The only way to continue the teaching-learning process was through online teaching only. Therefore, EFL teachers needed to be prepared for online delivery of instruction which was not the need in other situations. Hence, this study is significant.

Nevertheless, this study tries to overcome some limitations. Firstly, data were collected through snowball sampling, which could not be as representative as it should have been to cover the target population. Secondly, responses were received only from those EFL teachers who had access to the Internet and were younger (56\%), below 25 years of age groups. Thirdly, as this questionnaire adopted a digital Google Docs format for the survey inviting teachers to respond via email and Google form mode, it required some digital literacy to respond and submit the questionnaire.

\section{Conclusion}

This study has surveyed the Nepalese EFL teachers' digital literacy skills necessary for online teaching at school level education. Due to the global pandemic of COVID-19, face-to-face classes have been suspended, making teachers compelled to be prepared for an online teaching mode. As online instruction requires basic computer skills and digital knowledge, EFL teachers have to prepare themselves with these skills to run through a distance mode of teaching using technology.

This study found that most secondary school-level English teachers had prepared themselves for online instruction with necessary technological skills. They were prepared for online instruction because they got a chance to learn digital skills at home due to lockdown, although most schools had no provision for this teaching mode. School administrations must make provision for online teaching until the coronavirus pandemic is controlled. Schools cannot be closed, and teaching-learning activities cannot be suspended for so long as it would seriously affect children's learning. Yet, this study implies that all teachers in general and
English teachers specifically need to be prepared with digital literacy and skills for online teaching. Their readiness for online teaching can open the door for running teaching and learning activities. Through teacher readiness, they might compel the government and the schools toward this mode of instruction with necessary infrastructures and management. The effectiveness of online teaching in rural Nepal merits further research.

\section{Acknowledgement}

I would like to thank the three anonymous reviewers for their constructive feedback to improve this article. I have no conflict of interest.

\section{References}

Abdulamir, A. S., \& Hafidh, R. R. (2020). The possible immunological pathways for the variable Immunopathogenesis of COVID-19 infections among healthy adults, elderly and children. Electronic Journal of General Medicine, 17(4), $1-4$. https://doi.org/10.29333/ejgm/7850

Acharya, C. P. (2014). Use of ICT/web tools in ELT in Nepal. Journal of NELTA, 19(1-2), 1-16.

Aliyyah, R. R., Rachmadtullah, R., Samsudin, A., Syaodih, E., Nurtanto, M., \& Tambunan, A. R. S. (2020). The perceptions of primary school teachers of online learning during the COVID-19 pandemic period: A case study in Indonesia. Journal of Ethnic and Cultural Studies, 7(2), 90-109.

Atmojo, A. E. P., \& Nugroho, A. (2020). EFL classes must go online! Teaching activities and challenges during COVID-19 pandemic in Indonesia. Register Journal, 13(1), 49-76.

Aydin, S. (2013). Teachers' perceptions about the use of computers in EFL teaching and learning: The case of Turkey. Computer Assisted Language Learning, 26(3), 214-233.

Basilaia, G., \& Kvavadze, D. (2020). Transition to online education in schools during a SARS-CoV2 coronavirus (COVID-19) pandemic in Georgia. Pedagogical Research, 5(4), 1-9.

Çam, E., \& Kiyici, M. (2017). Perceptions of prospective teachers on digital literacy. Malaysian Online Journal of Educational Technology, 5(4), 29-44.

Chen, Y. L. (2008). A mixed-method study of EFL teachers' Internet use in language instruction. Teaching and Teacher Education, 24(4), 1015-1028. 
Chung, E., Subramaniam, G., \& Dass, L. C. (2020). Online learning readiness among university students in Malaysia amidst Covid-19. Asian Journal of University Education, 16(2), 45-58.

Cote, T., \& Milliner, B. (2018). A survey of EFL teachers' digital literacy: A report from a Japanese university. Teaching English with Technology, 18(4), 71-89.

Daniel, S. J. (2020). Education and the COVID-19 pandemic. Prospects, 1-6.

Dashtestani, R. \& Hojatpanah, S. (2020). Digital literacy of EFL students in a junior high school in Iran: voices of teachers, students and Ministry Directors. Computer Assisted Language Learning, 1-31. https://doi.org/10.1080/09588221.2020.1744664

Dhawan, S. (2020). Online learning: A panacea in the time of COVID-19 crisis. Journal of Educational Technology Systems, 49(1), 5-22.

Digital Literacy Task Force. (2013). Digital literacy, libraries, and public policy. Report of the Office of Information Technology Policy's Digital Literacy Task Force. Retrieved from http://www.districtdispatch.org/wpcontent/uploads/2013/01/2012_OITPdigilitreport_1_22_13.pdf

Lawrence, S. A., \& Calhoun, F. (2013). Exploring teachers' perceptions of literacy and use of technology in classroom practice: Analysis of selfreported practice in one school district. Journal of Literacy and Technology, 14(1), 51-71.

MacIntyre, P. D., Gregersen, T., \& Mercer, S. (2020). Language teachers' coping strategies during the Covid-19 conversion to online teaching: Correlations with stress, wellbeing and negative emotions. System. https://doi.org/10.1016/j.system.2020.102352

Mishra, P., \& Koehler, M. J. (2006). Technological pedagogical content knowledge: A framework for teacher knowledge. Teachers College Record, 108(6), 1017-1054.

Moorhouse, B. L. (2020). Adaptations to a face-to-face initial teacher education course 'forced'online due to the COVID-19 pandemic. Journal of Education for Teaching, 1-3 https://doi.org/10.1080/02607476.2020.1755205

Mudra, H. (2020). Digital literacy among young learners: How do EFL teachers and learners view its benefits and barriers?. Teaching English with Technology, 20(3), 3-24.
Rana, K., Greenwood, J., Fox-Turnbull, W., \& Wise, S. (2018). A shift from traditional pedagogy in Nepali Rural Primary Schools? Rural teachers' capacity to reflect ICT policy in their practice. International Journal of Education and Development using ICT, 14(3).

Son, J. B., Robb, T., \& Charismiadji, I. (2011). Computer literacy and competency: A survey of Indonesian teachers of English as a foreign language. Computer-Assisted Language Learning Electronic Journal (CALL-EJ), 12(1), 26-42.

Thapaliya, M. P. (2014). English teachers' perceptions and practices of information and communication technologies (ICTs) in Kathmandu district, Nepal. International Journal of Academic Research in Education and Review, 2(10), 251258.

Uscher-Pines, L., Schwartz, H. L., Ahmed, F., Zheteyeva, Y., Meza, E., Baker, G., \& Uzicanin, A. (2018). School practices to promote social distancing in K-12 schools: review of influenza pandemic policies and practices. BMC Public Health, 18(1). $\quad$ https://doi.org/10.1186/s12889018-5302-3 